\title{
Interrelation of mental "burn out" level and psychological health in athletes with different qualification
}

\author{
Nagovitsyn R.S. ${ }^{1 \mathrm{ADE}}$, Miroshnichenko A.A. ${ }^{1 \mathrm{ABD}}$, Merzlyakova D.R. ${ }^{2 \mathrm{BCE}}$, Faizullina G.Z. ${ }^{3 \mathrm{CDE}}$ \\ ${ }^{1}$ Glazov State Pedagogical Institute, Russia \\ ${ }^{2}$ Udmurt State University, Russia \\ ${ }^{3}$ Udmurt School "Harmony”, Russia
}

Authors' Contribution: A - Study design; B - Data collection; C - Statistical analysis; D - Manuscript Preparation; E - Funds Collection.

\begin{abstract}
Purpose: $\quad$ to reveal features of psychological health and characteristics of personal development and mental "burn out" of athletes with different qualification.

Material: $\quad$ the comparative analysis of mental expression of "burn out" in samples of athletes with different qualification $(n=187)$. We tested men $(n=110)$ and women $(n=77)$ aged from 15 up to 29 years old. Athletes represented the following kinds of sport: boxing, fight, basketball, gymnastics, swimming, volleyball. They were divided into 2 groups: high qualification (Candidates and Masters of Sports, $n=89$ ) and low qualification $(n=98)$.

Results: it is observed a lot of positive correlation interrelations between indicators of psychological health and mental "burn out" of athletes. In the group of high qualification athletes, the indicators of psychological health are connected with reduction of achievement feeling and depreciation of achievements. In the group of low qualification athletes they were mainly connected with reduction of achievement feeling. The high qualification athletes are more subject to mental "burn out". It is connected with higher psychophysiological loads. These athletes are more inclined to creativity, humanity, are more intellectually developed. For low qualification athletes, the family sphere of life is more important.

Conclusions: the received results testify to need of psychological support of training of athletes with different qualification to prevention and correction of mental "burn out" and maintenance of psychological health.

Keywords: athletes, psychological health, mental burn out, boxing, fight, basketball, gymnastics, swimming, volleyball.
\end{abstract}

\section{Introduction}

In modern sports, athletes are under maximum loads. The specifics of sport define mental features of professional activity of the athlete and allow to reveal the negative factors influencing his psychology. The more extreme is a certain sport, the more stressful factors affect the psychological sphere of the athlete [1].

A lot of authors considered aspects of the influence of stressful, difficult, special and extreme conditions of sports activity on athletes' mentality [2, 3]. The main task of researchers most often is the justification of ways and opportunities of psychological resources activation and search of ways of the maximum mobilization of forces for a victory in competitions $[4,5]$. It was made attempts to define the influence of sports activity conditions on the psychological health of athletes [6,7] of different qualification categories [8,9]. Researches of physical activities influence on the psychological health of athletes show positive $[10,11]$, neutral [12] and negative $[13,14]$ of their influence.

It is also offered a number of psychological technologies promoting the safety of athletes practicing extreme sports [15]. The interrelation of psychological health condition and athletes" "burn out" were analyzed only in separate researches [16]. Authors carried out the search for ways to decrease emotional distress and the negative effect of physical activities on mentality. Psychological health is

\footnotetext{
(C) Nagovitsyn R.S., Miroshnichenko A.A., Merzlyakova D.R.,

Faizullina G.Z., 2018

doi:10.15561/20755279.2018.0608
}

one of the most important characteristics of a person's identity [17]. A basis of psychological health is full mental development at all stages of development. Psychological health means harmony of the person with the environment and various components of his personality: rational and emotional, mental and corporal, reason, and intuition [18]. The maintenance and formation of psychological health is a complex process. It has to begin with the early childhood. Such a process has to cover all levels of the education system and provide interaction of all participants of the educational relations. It is necessary to apply qualimetric methods (for example, pedagogical examination) for the choice of the optimum model of such extent and interaction [19].

A lot of authors considered the person as a system. Authors considered that health presupposes a certain level of personality integration [9]. This determination of health is similar to a concept of psychological health of the person [20, 21]. There were attempts to determine the criteria of psychological health of athletes irrespective of their experience, skill level, and an experience. The criteria of psychological health of athletes were indicators of adaptedness, stability and "self-adjustability" [12]. The syndrome of "burn out" in athletes has the specifics connection with the increase of mental and physical loads $[22,23]$. There is no one point of view on the definition of "burn out" phenomenon in modern science.

The purpose of the research is to reveal the features of psychological health and characteristics of personal development and mental "burn out" in athletes with 
different qualification.

\section{Material and methods}

Participants: the comparative analysis of mental "burn out" expression was performed in samples of athletes with different qualification $(n=187)$. We tested men $(n=110)$ and women $(n=77)$ aged from 15 up to 29 years. Athletes were representatives of the following sports: boxing, fight, basketball, gymnastics, swimming, volleyball. Athletes were divided into 2 groups: high qualification (Candidates and Masters of Sports, $\mathrm{n}=89$ ) and low qualification $(\mathrm{n}=98)$.

Organization of a research: empirical methods were applied: the questionnaire of emotional "burn out" of ABQ (Athlete Burnout Questionnaire) developed by Raedeke and Smith in the adaptation of Berilova [24]; the technique of diagnostics of psychological health of Kozlov A.V. including various personal and psychological scales [17].

Statistical analysis: mathematic-statistical data processing was performed by means of an "SPSS 22.0" statistical programs considering normality of sample distribution. The Student's t-test was applied for independent samples. The analysis of interrelation of indicators of psychological health and symptoms of mental "burn out" was carried out by means of calculation of Pearson coefficient.

\section{Results}

Processing of average values of "burn out" indicators demonstrated reduction of achievement feeling in high qualification athletes $(\bar{x}=12,53)$ in comparison with low qualification athletes $(\bar{x}=8,49)(\mathrm{t}=6,70 ; \mathrm{p} \leq 0,05)$ (Tab. 1). The high qualification athletes have also more expressed emotional and physical exhaustion $(\bar{x}=8,30)$ in comparison with low qualification athletes $(\bar{x}=4,30)$ $(\mathrm{t}=4,64 ; \mathrm{p} \leq 0,05)$. Depreciation of the own achievements is characteristic of high qualification athletes $(\bar{x}=8,97)$ in comparison with low qualification athletes $(\bar{x}=4,73)$ $(\mathrm{t}=5,25 ; \mathrm{p} \leq 0,05)$. At the same time it should be noted that indicators of mental "burn out" symptoms in high qualification athletes are at the level of average values. These indicators in low qualification athletes are at the low level. The high qualification athletes have a tendency to development of mental "burn out" syndrome. Therefore it is necessary to implement measures for symptoms control of this psychological phenomenon. Otherwise, adaptation opportunities of an organism will be incapable to maintain further psychological and physiological loads.

Thus, high qualification athletes "pay" higher psychophysiological price for the sports achievements in comparison with real opportunities. As a result they have a tendency to unwillingness to achieve high results, to depreciate them. Reduce in athletes motivation is followed by a condition of emotional and physical exhaustion.

The analysis of data, allows to mark out peculiar to high qualification athletes tendency to creativity $(\bar{x}=6,20)$, higher IQ $(\bar{x}=8,56)$, tendency to humanity $(\bar{x}=5,24)$. The received indicators at both groups of athletes correspond to average values. The exception is IQ. The low qualification athletes have an average level of intelligence. The high qualification athletes have high IQ. The tendency to creativity, humanistic orientation promotes disclosure of athlete's potential, helps him to achieve new results. For low qualification athletes $(\bar{x}=6,35)$ the family sphere of life in comparison with high qualification athletes is more significant $(\bar{x}=6,04)(\mathrm{t}=22,49 ; \mathrm{p} \leq 0,05) \quad$ (Tab. 1). This indicator also is in limits of average values. It means that high qualification athletes are limited in communication with close people and this sphere isn't important for them.

The values of correlation coefficients between indicators of mental "burn out" and psychological health in high qualification athletes sample are presented in Tab. 2.

The comparative analysis of mental "burn out" expression in samples of athletes with different qualification showed that in athletes sample is observed a lot of positive correlation interrelations between indicators of psychological health and mental "burn out". At the same time in the group of high qualification athletes the indicators of psychological health are connected with reduction of achievement feeling and depreciation of achievements. And in a group of low qualification athletes is mainly connected with reduction of achievement feeling.

Results of a research demonstrate that $34 \%$ of athletes

Table 1. Statistical indicators of high and low qualification athletes $(n=187)$

\begin{tabular}{lllll}
\hline \multirow{2}{*}{ Indicators } & \multicolumn{2}{l}{$\begin{array}{l}\text { Average indicators values in athletes } \bar{x} \\
\text { high-qualification }\end{array}$} & $\begin{array}{l}\text { Student's } \\
\text { low-qualification }\end{array}$ & $\begin{array}{l}\text { Level of } \mathbf{p} \\
\text { significance }\end{array}$ \\
\hline Reduction of achievement feeling & 12.53 & 6.70 & 6.06 & 0.04 \\
Emotional and physical exhaustion & 8.30 & 4.30 & 4.64 & 0.001 \\
Depreciation of achievements & 8.97 & 4.73 & 5.25 & 0.001 \\
Creative vector & 6.2 & 5.11 & 7.85 & 0.001 \\
Intellectual vector & 8.56 & 6.1 & 7.48 & 0.001 \\
Family vector & 6.04 & 6.35 & 5.24 & 0.008 \\
Humanistic vector & 5.24 & 4.20 & 8.89 & 0.001 \\
\hline
\end{tabular}


Table 2. Correlation coefficients between indicators of mental "burn out" and psychological health in high qualification athletes sample

\begin{tabular}{lllll}
\hline $\begin{array}{l}\text { Indicators of } \\
\text { psychological health }\end{array}$ & $\begin{array}{l}\text { Indicators of mental «burn out» } \\
\text { Integrated } \\
\text { indicator of } \\
\text { mental «burn } \\
\text { out» }\end{array}$ & $\begin{array}{l}\text { Reduction of } \\
\text { achievement } \\
\text { feeling }\end{array}$ & $\begin{array}{l}\text { Emotional and } \\
\text { physical exhaustion }\end{array}$ & $\begin{array}{l}\text { Depreciation of } \\
\text { achievements }\end{array}$ \\
\hline Strategic vector & $-0.393^{* *}$ & -0.195 & $-0.594^{* *}$ & -0.188 \\
I-vector & $0.237^{*}$ & 0.060 & 0.104 & $0.228^{*}$ \\
Intellectual vector & -0.516 & $0.455^{* *}$ & -0.177 & $-0.743^{* *}$ \\
Humanistic vector & 0.121 & $0.289^{* *}$ & $-0.477^{* *}$ & 0.206 \\
Creative vector & 0.165 & 0.032 & $-0.402^{* *}$ & $0.333^{* *}$ \\
Family vector & 0.134 & $0.478^{* *}$ & 0.104 & -0.062 \\
Pro-social vector & $-0.238^{*}$ & $-0.364^{* *}$ & $-0.365^{* *}$ & -0.015 \\
Spiritual vector & -0.011 & $0,437^{* *}$ & 0.000 & -0.185 \\
\hline
\end{tabular}

Note: ${ }^{*} \mathrm{p} \leq 0,05 ;{ }^{*} \mathrm{p} \leq 0,01$

Table 3. Correlation coefficients between indicators of mental "burn out" and psychological health in low qualification athletes sample

\begin{tabular}{lllll}
\hline $\begin{array}{l}\text { Indicators of } \\
\text { psychological health }\end{array}$ & $\begin{array}{l}\text { Indicators of mental «burn out» } \\
\text { Integrated } \\
\text { indicator of mental } \\
\text { «burn out» }\end{array}$ & $\begin{array}{l}\text { Reduction } \\
\text { of feeling of } \\
\text { achievement }\end{array}$ & $\begin{array}{l}\text { Emotional and } \\
\text { physical exhaustion }\end{array}$ & $\begin{array}{l}\text { Depreciation of } \\
\text { achievements }\end{array}$ \\
\hline Strategic vector & $-0.282^{* *}$ & -0.012 & -0.126 & $-0.425^{* *}$ \\
I-vector & $-0.332^{* *}$ & 0.044 & $-0.569 * *$ & $-0.334^{* *}$ \\
Intellectual vector & -0.162 & -0.058 & $-0.230^{*}$ & -0.131 \\
Humanistic vector & -0.134 & 0.003 & 0.045 & $-0.261^{* *}$ \\
Creative vector & $-0.448^{* *}$ & -0.056 & $-0.462^{* *}$ & $-0.521^{* *}$ \\
Family vector & 0.119 & $0.456^{* *}$ & -0.188 & -0.017 \\
Pro-social vector & $-0.667^{* *}$ & $0.456^{* *}$ & -0.188 & -0.017 \\
Spiritual vector & $-0.211^{*}$ & -0.316 & -0.422 & $-0.744^{* *}$ \\
\hline
\end{tabular}

Note: ${ }^{*} \mathrm{p} \leq 0,05 ;{ }^{*} \mathrm{p} \leq 0,01$

have average levels of mental "burn out" symptoms expression. The analysis of average values in the general sample showed maximum symptom expression of "reduction of achievement feeling". Emotional and physical exhaustion and depreciation of achievements aren't expressed to the full extent.

\section{Discussion}

The received results of research supplement data on the interrelation of mental "burn out" level and psychological health in athletes with different qualification [5,9]. Our results reveal the depth of complete understanding of athletes training process improvement depending on quantitative data from the more significant sample. So the similar results were received in the research of Lee at el. [25]: high level of a stress had the strong correlation with burn out, and the high level of burn out was negatively connected with athletic identity and satisfaction of the athlete. Authors experimentally proved that "burn out" have a full mediation of interrelation between a stress and identity of the athlete. Practical results of the real research allow to expand possibilities to increase in efficiency of the training process on the basis of the individual differentiated psychological preparation.

In the researches of Gustafsson at el [22] and Gerber at el [23] indicators of mental "burn out" are analyzed through a prism of responses level to a chronic stress. Such stress includes psychological, emotional and physical leaving from the activity. Though such earlier stress was a source of pleasure and positive emotions of the athlete. In our research indicators of mental "burn out" are experimentally shown in scales of reduction of achievement feeling, emotional and physical exhaustion and depreciation of achievements.

It should be noted, the concept of mental "burn out" syndrome of Raedeke [21]. Its basis was formed by the theory of mental "burn out" of Maslach and Jackson. This model includes three components: reduction of achievement feeling which is shown in decrease in aspiration of the athlete to achieve good results in the 
activity; the depreciation of sports achievements consisting in decrease in the importance of the achieved results for the athlete; emotional or physical exhaustion which is shown in emotional and physical fatigue of athletes (when there is no desire anymore and forces to be engaged in sports activity) $[20,21]$. The tendency to development of mental "burn out" syndrome is observed in high qualification athletes [22]. The necessity of symptom control of this psychological phenomenon is experimentally proved. Otherwise, adaptation opportunities of an organism will be incapable to maintain further psychological and physiological loads [18]. Results of our research revealed the important directions and qualification characteristics of levels of a competitive cycle of preparation. In a group of low qualification athletes it is revealed that at high rates of psychological health the risk of emergence of mental "burn out" symptoms decreases. The exception is decrease in achievement feeling at high values of family and pro-social factors. The mental "burn out" syndrome is most brightly expressed in those athletes who are incapable to adapt to long stressful factors [2]. According to our opinion, identification of interrelation indicators of psychological health and mental "burn out" of athletes will allow to carry out work on psychological escort of athletes considering "weak" aspects of adaptation.

\section{Conclusions}

1. The high level of mental "burn out" provokes maximum expression of "I-vector" in high qualification athletes. Reduction of achievement feeling is peculiar to athletes with high IQ, spiritual and humanistic orientation. Depreciation of achievements is connected with orientation on itself and tendency to creativity.

2. The high qualification athletes are more subject to mental "burn out". It is connected with higher psychophysiological loads. At the same time features of psychological health of different qualification athletes were revealed. The family sphere of life is more important for the low qualification athletes.

3. Indicators of psychological health of high qualification athletes are connected with reduction of achievement feeling and depreciation of achievements. Indicators of psychological health of low qualification athletes group mainly depend on reduction of achievement feeling.

4. Results of a research testify to need of psychological support of athletes training to prevent and correct mental "burn out" and maintenance of psychological health.

\section{Conflicts of Interest}

There is not any conflict of interest to be declared regarding the manuscript.

\section{References}

1. Hudson J, Day MC. Athletes' experiences of expressive writing about sport stressors. Psychology of Sport and Exercise, 2012;13(6):798-806. https://doi.org/10.1016/j.psychsport.2012.05.005

2. Karpov VY. Perfection of means of self-regulation of a mental condition of hockey players of the top skills in game activity. Cand. Diss., Chelyabinsk; 2002. (in Russian)

3. Nebytova LA. Psychological support of the formation of the reliability of the subject of sports activity. Cand. Diss., Stavropol; 2004. (in Russian)

4. Carless D, Sparkes AC. The physical activity experience of men with serious mental illness: Three short stories. Psychology of Sport and Exercise, 2008;9:191-210. https://doi.org/10.1016/j.psychsport.2007.03.008

5. Grin YI. Personnel resources for overcoming mental burnout in athletes. Cand. Diss., Krasnodar; 2009. (in Russian)

6. Kaiseler M, Polman R, Nicholls A. Mental toughness, stress appraisal coping and coping effectiveness in sport. Personality and individual differences, 2009;47(7):728-733. https://doi.org/10.1016/j.paid.2009.06.012

7. Stănescu M, Vasile L. Using Physical Exercises to improve Mental Health. Procedia-Social and Behavioral Sciences. 2014;149:921 - 926. https://doi.org/10.1016/j.sbspro.2014.08.289

8. Howells K, Fletcher D. Sink or swim: Adversity and growthrelated experience in Olympic swimming champions. Psychology of Sport and Exercise, 2015;16(3):37-48. https://doi.org/10.1016/j.psychsport.2014.08.004

9. Schinke RJ, Stambulova NB, Si G, Moore Z. International society of sport psychology position stand: Athletes' mental health, performance, and development. International Journal of Sport and Exercise Psychology, 2017:1-18. https://doi.org/10.1080/1612197X.2017.1295557

10.Nagovitsyn RS, Chigovskaya-Nazarova YA,
Miroshnichenko AA, Senator SY. The Realization of the System Programme "Health Saving Education" in the Pedagogical University. European Journal of Contemporary Education, 2018;7(1): 137-149. https://doi.org/10.13187/ejced.2018.1.137

11.Paluska SA, Schwenk TL. Physical activity and mental health: current concepts. Sport Medicine, 2000;29(3):167 - 180. https://doi.org/10.2165/00007256-200029030-00003

12.Aloshicheva AV Psychological health of professional sportsmen engaged in extreme sports. Vestnik Kemerovskogo gosudarstvennogo universiteta, 2016;3:38-44 (in Russian)

13.Caddick N, Smith B. The impact of sport and physical activity on the well-being of combat veterans: A systematic review. Psychology of Sport and Exercise, 2014;15:9-18. https://doi.org/10.1016/j.psychsport.2013.09.011

14.Culliver A, Griffiths KM, Mackinnon A, Batterham PJ, Stanimirovic R. The mental of Australian elite athletes. Journal of Science and Medicine in Sport, 2015;18(3):255-261. https://doi.org/10.1016/j.jsams.2014.04.006

15. GlenisterD. Exercise and mental health: areview. Journal of the Royal Society for the Promotion of Health, 1996;116(1):7-13. https://doi.org/10.1177/146642409611600102

16.Golub YV, Baryayev AA, Banayan AA, Yemel'yanov VD. Correction of professional burnout in high-qualified sportsmen by combined use of auto-training and lightsound stimulation. Adaptivnaya fizicheskaya kul'tura, 2015;4(64):23-25 (in Russian)

17.Kozlov AV. Methods of diagnosing psychological health. Perspektivy nauki i obrazovaniya, 2014; 6(12):110-117 (in Russian)

18. Markati A, Psychountaki M, Kingston K, Karteroliotis K, Apostolidis N. Psychological and situational determinants of burnout in adolescent athletes. International Journal of Sport and Exercise Psychology, 2018:1-16. https://doi.org/10.1080/1612197X.2017.1421680 
19.Miroshnichenko AA, Merzlyakova DR. Regional System of Providing the Psychological Health $f$ Participants of Educational Relations: Qualimetry Aspect. The bulletin of Kalashnikov Izhevsk State Technical University, 2017;2:172-176. (in Russian) https://doi.org/10.22213/2413-1172-2017-2-172-176

20.Ilin YP. Psychology of sports. St. Petersburg: Piter; 2008. (in Russian)

21.Raedeke TD, Smith AL. Development and Preliminary Validation of an Athlete Burnout Measure. Journal of Sport \& Exercise Psychology, 2001;23(4):281-306. https://doi.org/10.1123/jsep.23.4.281

22.Gustafsson H, Carlin M, Podlog L, Stenling A, Lindwall M. Motivational profiles and burnout in elite athletes: A person-centered approach. Psychology of Sport and Exercise, 2018;35:118-125. https://doi.org/10.1016/j.psychsport.2017.11.009
23.Gerber M, Best S, Meerstetter F, Walter M, Ludyga S, Brand $\mathrm{S}$, et al. Effects of stress and mental toughness on burnout and depressive symptoms: A prospective study with young elite athletes. Journal of Science and Medicine in Sport, 2018; 21(12):1200-1205. https://doi.org/10.1016/j.jsams.2018.05.018

24.Berilova YI Adaptation of the questionnaire T. Raedeke, A. Smith for the assessment of mental burnout in Russian athletes. Fizicheskaya kul'tura, sport - nauka i praktika, 2016;4:79-84. (in Russian)

25.Lee K, Kang S, Kim I Relationships Among Stress, Burnout, Athletic Identity, and Athlete Satisfaction in Students at Korea's Physical Education High Schools. Psychological Reports, 2017;120(4):585-608. https://doi.org/10.1177/0033294117698465

\section{Information about the authors:}

Nagovitsyn R.S. (Corresponding author); http://orcid.org/0000-0003-4471-0875; gto18@mail.ru; Glazov State Pedagogical Institute; Pervomaiskaya Street, 25, Glazov,427620, Russia.

Miroshnichenko A.A.: http://orcid.org/0000-0002-2845-3437; ggpi@mail.ru; Glazov State Pedagogical Institute; Pervomaiskaya Street, 25, Glazov,427620, Russia.

Merzlyakova D.R.: http://orcid.org/0000-0003-4825-3181; dinamerzlyakova26@gmail.com; Udmurt State University;University Street, 1, Izhevsk, 426034, Russia.

Faizullina G.Z.: http://orcid.org/0000-0002-6705-3911; gulifay@mail.ru; School “Harmony”; K. Libknekht Street, 24, Izhevsk, 426077, Russia.

Cite this article as: Nagovitsyn RS, Miroshnichenko AA, Merzlyakova DR, Faizullina GZ. Interrelation of mental "burn out" level and psychological health in athletes with different qualification. Physical education of students, 2018;22(6):327-331. doi:10.15561/20755279.2018.0608

The electronic version of this article is the complete one and can be found online at: http://www.sportedu.org.ua/index.php/ PES/issue/archive

This is an Open Access article distributed under the terms of the Creative Commons Attribution License, which permits unrestricted use, distribution, and reproduction in any medium, provided the original work is properly cited (http:// creativecommons.org/licenses/by/4.0/deed.en).

Received: 09.07.2018

Accepted: 12.08.2018; Published: 26.12.2018 